QL235

. R5

B7

1909

Britton, N

L

Rhipsalis in the $\mathrm{W}_{\mathrm{e}^{\mathrm{st}}}$ Indies 


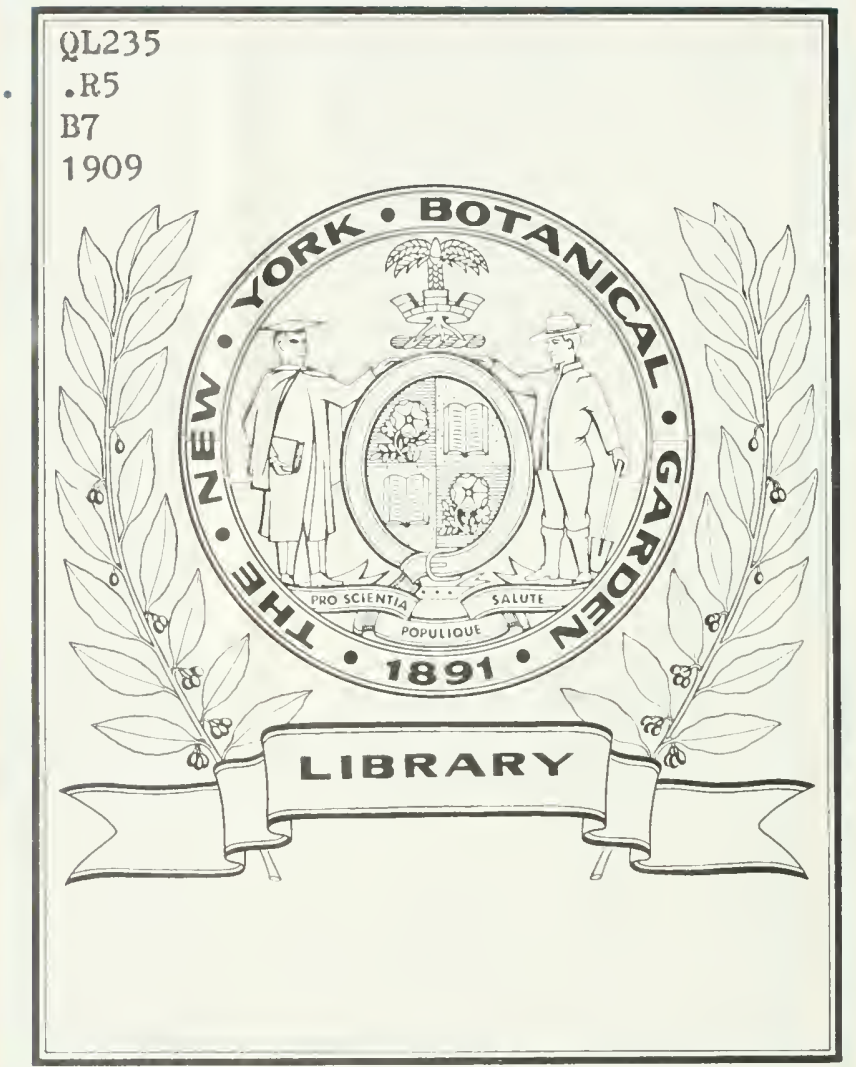


CONTRIBUTIONS FROM THE NEW YORK BOTANICAL GARDEN-No. 124

\title{
RHIPSALIS IN THE WEST INDIES
}

\author{
By N. L. BRITTON
}

\section{NEW YORK \\ 1909}


.85
87
197
199 


\title{
LIBRARY \\ NEW YORK \\ IITANICAL \\ GARUEN.
}

\section{RHIPSALIS IN THE, WEST INDIES *}

\author{
BY N. L. BRitToN
}

Rhipsalis is a genus of leafless jointed cacti, with round, angled, or flat branches and small flowers, consisting of numerous species, mostly natives of tropical America, but a few species occur in eastern tropical Africa and the widely distributed $R$. Cassutha grows also in Ceylon. In this Old World distribution the genus differs from all other cacti, the family being otherwise American in distribution, except for several Opuntias, which have become naturalized in southern Europe and northern Africa.

These African species are of great interest from the standpoint of geographic distribution because they are the only cacti native in any part of the Old World. From the large preponderance of species in America it seems certain that the ancestors of the African kinds must have been transported from the American tropics to those of Africa in past geologic time, and the method of transportation, unless there was land connection between the continents, can only be guessed at. There are many genera in other families of plants common to the American and African tropics, however, and this indicates the probability of former land connection, over which their ancestors might have spread by well-known natural means.

The genus was established by Gaertner (Fruct. \& Sen. I : I 37. I 788), the type species being $R$. Cassutha Gaertn. Adanson (Fam. Pl. 2: 243. I 763 ) had previously proposed the generic name Hariota, for presumably the same species (Plumier, Plant. Amer. 190. p!. 197.f. 2), and this figure is cited by Linnaeus. (Syst. ed. 10, 1054. I 759) under Cactus parasiticus, but Linnaeus at the same place, and before his citation of Plumier's figure,

* Illustrated with the aid of the Catherine McManes Fund. 
cites Sloane. Jamaica, pl. 22f. f. 3 and $f$ which is a species of Vanilla, probably $V$. Eggo rsiana Rolfe. Inasmuch as Adanson did not typify Hariote binominally, and as the type of Cactus parasiticus L. is a Vemila, it would appear that the name Hariota must be passed over, although it was taken up by Dr. Otto Kuntze (Rev. Gen. Pl. 26I. I 89I), and the species of Rhipsalis

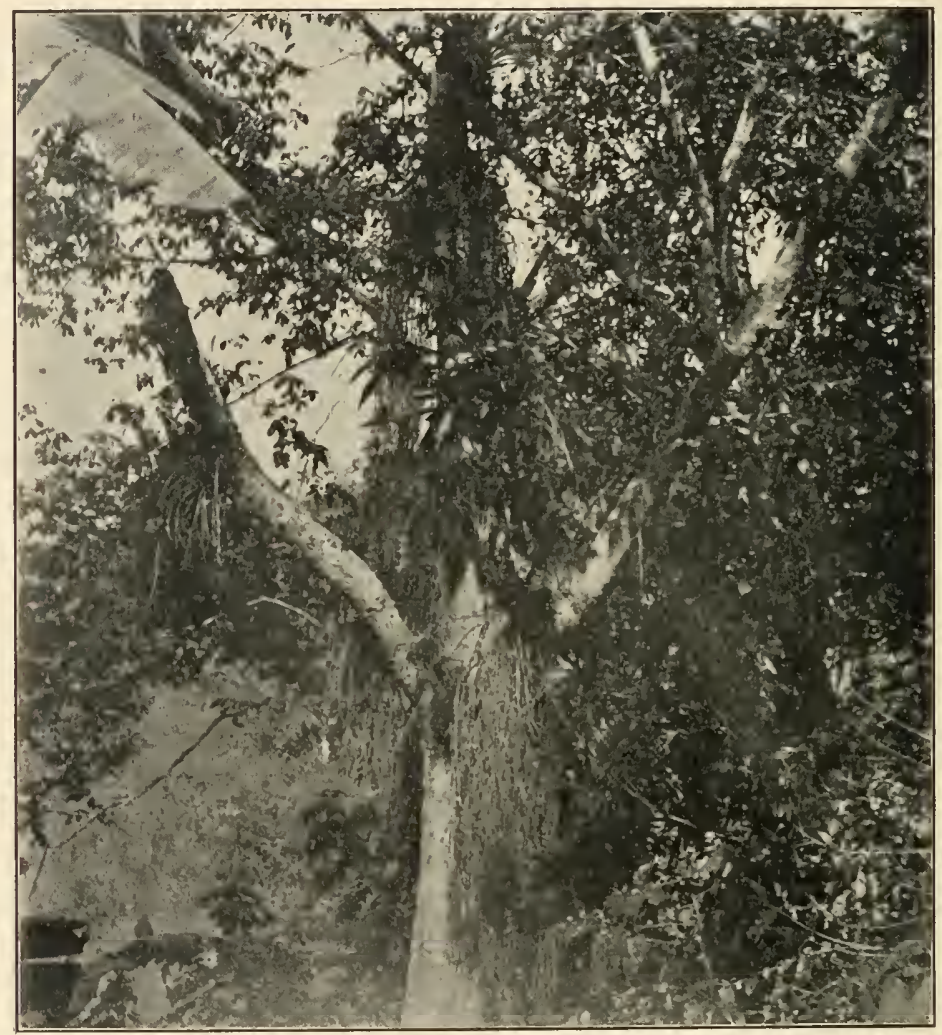

Hur I. Khipinlis Cussuha Gaertn. Near Utuado, Purto Rico. Photographed by Dr. Marshall A. Ilowe.

known to him transferred to it. Through Linnaeus's blunder of uniting tivo widely different plants, which he knew only from illustrations, we are apparently prevented from using the name Huriota, and the next oldest available generic name is Rhipsalis.

The species of Rhipsalis are mainly epiphytic, drooping from 
trees, though sometimes found on cliffs, and they are mesophytes rather than xerophytes, inhabiting moist or wet regions. Some of them bear spines or bristles at the areoles of young shoots, which usually fall away early, leaving the mature plants quite unarmed, but a few South American species bear spines even when mature. Their flowers are whitish, yellowish, or pink, often almost rotate when widely expanded, the perianth-segments few, the perianth-tube short or none; the stamens are few or numerous and shorter than the perianth; the fruits are globular or oblong, white or yellowish berries with a watery pulp full of small seeds.

Three species are now known from the West Indies, which may be classified as follows:

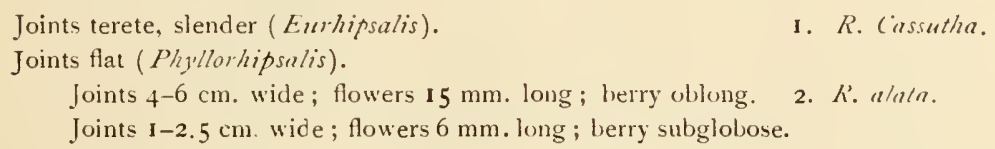

3. R. jumni,ensis.

I. Rhipsalis Cassutha Gaertn. Fr. \& Sem. I : I37. 1788 Cassytha fliformis Mill. Gard. Dict. Ed. 8. I 768. Not L. Cactus parasiticus Lam. Encycl. I : 54I. I783. Not L. Cactus pendulus Sw. Fl. Ind. Occ. 2: 876. 1800.

Cactus caripensis H.B.K. Nov. Gen. 6 : 66. 1823.

Cereus caripensis DC. Prodr. 3: 467. I \$28.

Rhipsalis parasiticus DC. Prodr. 3: 476. 1828 .

Cactus fasciulatus Willd. Enum. Suppl. 33. I 8 I 3.

Rhipsalis parasitica Haw. Syn. Pl. Succ. 187. 1812.

Rhipsalis fasciculata Haw. Suppl. 83. I 819.

Rhipsalis cassythoides G. Don, Gen. Syst. 3: I76. I 34.

Rhipsalis dichotoma G. Don, Gen. Syst. 3: I70. 1834 .

Rhipsalis undulata Pfeiff. Enum. I 56.1837.

Rhipsalis Hookeriana G. Don, Gen. Syst. 3: 176. 1834. Hariota parasitica Kuntze, Rev. Gen. Pl. 262. I 891.

Plant often I m. long or longer, much branched, light green, pendent from trees or on cliffs, the branches flexible ; flowers 6-8 mm. long; petals about 4, ovate, obtuse; stamens about 9 . [FIGURE I.]

TyPe LOCAlity: Not cited. 
Illustrations: Gaertn. loc. cit. pl. 28.f. I; Hook. Exot. Fl. I : pl. 2 ; Lodd. Bot. Cab. pl. 865 ; Bot. Mag. pl. 3079,3080 ; DC. Pl. Grasses, pl. 59 .

Distribution: Cuba: Matanzas (Rugel $767 ;$ Britton \& Shafer 450); Madruga (Britton \& Shofor 7SS); Calicita near Cienfuegos (Combs 770); vicinity of San Luis, Oriente (Pollard E Palmur 356; Maxon 4012). Haiti : Port Margot to Corneil (Nash 228); La Brande to Mt. Balance (Nash \& Taylor 1660). Pокто Rico: Yauco (Gartir 63; Sintems 3823); between Aibonito and Cayey (Heiler 516 ); near Aibonito (Underiood \& Griggs $7 \$ \delta)$. Jamaica: near Rio Grande Ford, Cuna Cuna Trail (Frcitholm 3207); Belvidere (Hurris 76+6); vicinity of Castleton (Maxon 836); Moneague (E. G. Britton 2956). San Luis Potosi, Mexico, to Costa Rica, Colombia, Bolivia, Venezuela, and Brazil. Tropical Africa. Mauritius. Ceylon.

The young shoots are often quite bristly, but the mature plant becomes smooth; flowers are sometimes developed before the bristles fall away. In the West Indies the plant has not been observed by me at a greater altitude than about 500 meters.

2. Rhipsalis alata (Si.) Schum. Fl. Bras. 4²: 288. I 890 Cactus alatus Sw. Prodr. 77. 1788.

Cereus alatus DC. Prodr. 3: 470. 1828.

Rhipsalis Szicartiana Pfeiff. Enum. 131. 1837.

Hariota alata Kuntze, Rev. Gen. I'l. 262. I891.

Rhipsalis Harrisii Gürle, Monats. Kakt. 18: I \&o. 1908.

Pendent from trees and on rocks, sometimes 5 meters long, with several long branches; joints broadly linear, lanceolate or linear-oblong, often constricted at the muddle or above it, bluntish at the apex, decurrent below into a stipe-like base, rather fleshy, bright green, about $1 \mathrm{~mm}$. thick, 2-4 dm. long, 4-6 cm. wide, the midvein prominent and stout, the margins crenate-undulate, the lower crenations $\mathrm{I}-2 \mathrm{~cm}$. long, the upper ones $4-8 \mathrm{~mm}$. long, the main lateral veins ending in the sinuses; flowers yellowishwhite, about $15 \mathrm{~mm}$. long; petals Io, lancenlate, acutish, the outer slightly longer than the inner, erect and nearly parallel; stamens numerous, about one half as long as the petals; style slender, about three times as long as the five linear stigmas; erry ovoid, rounded at both ends, yellow-gieen, $1 \mathrm{~cm}$. long. [FIGURE 2.] 


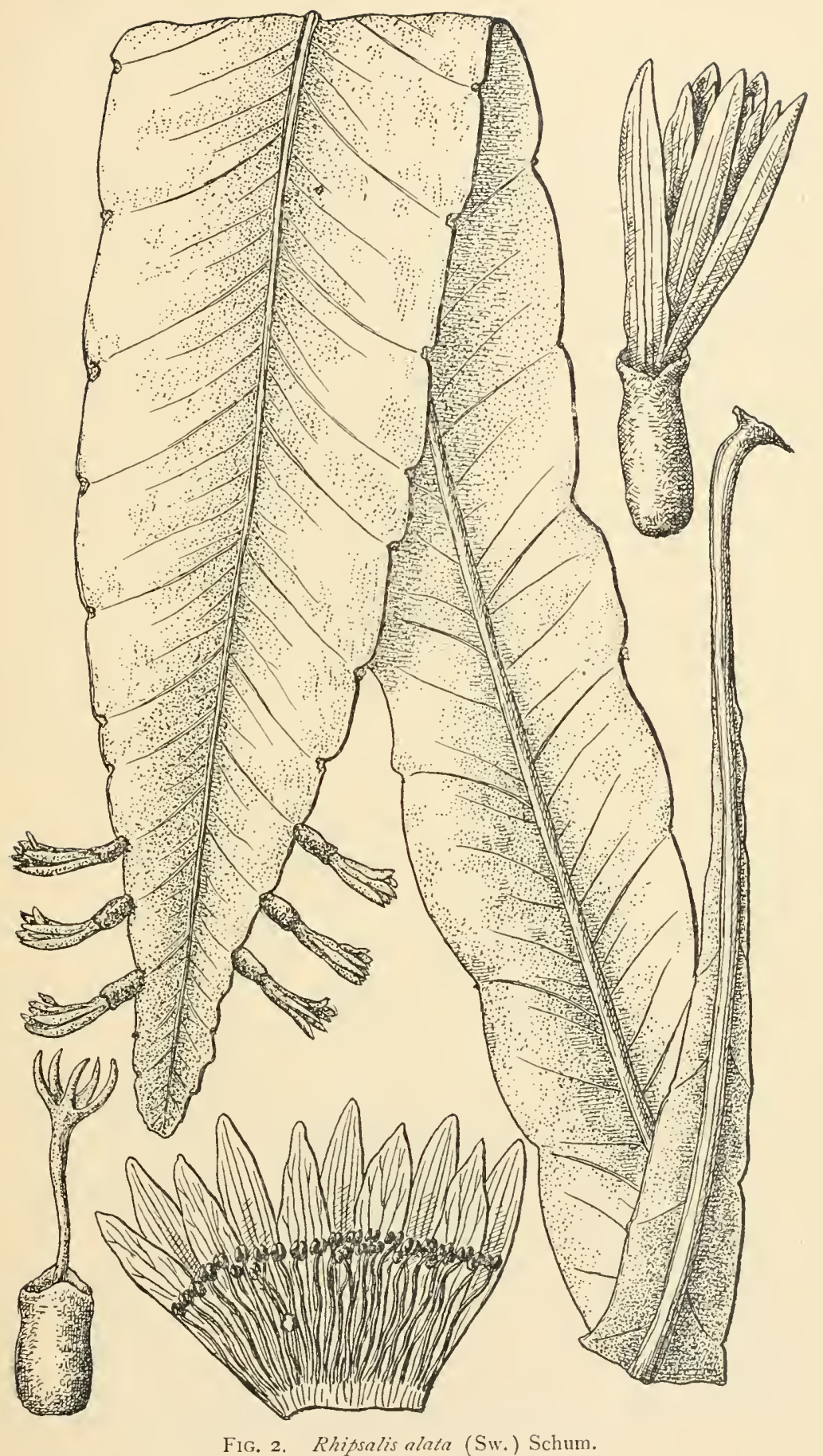




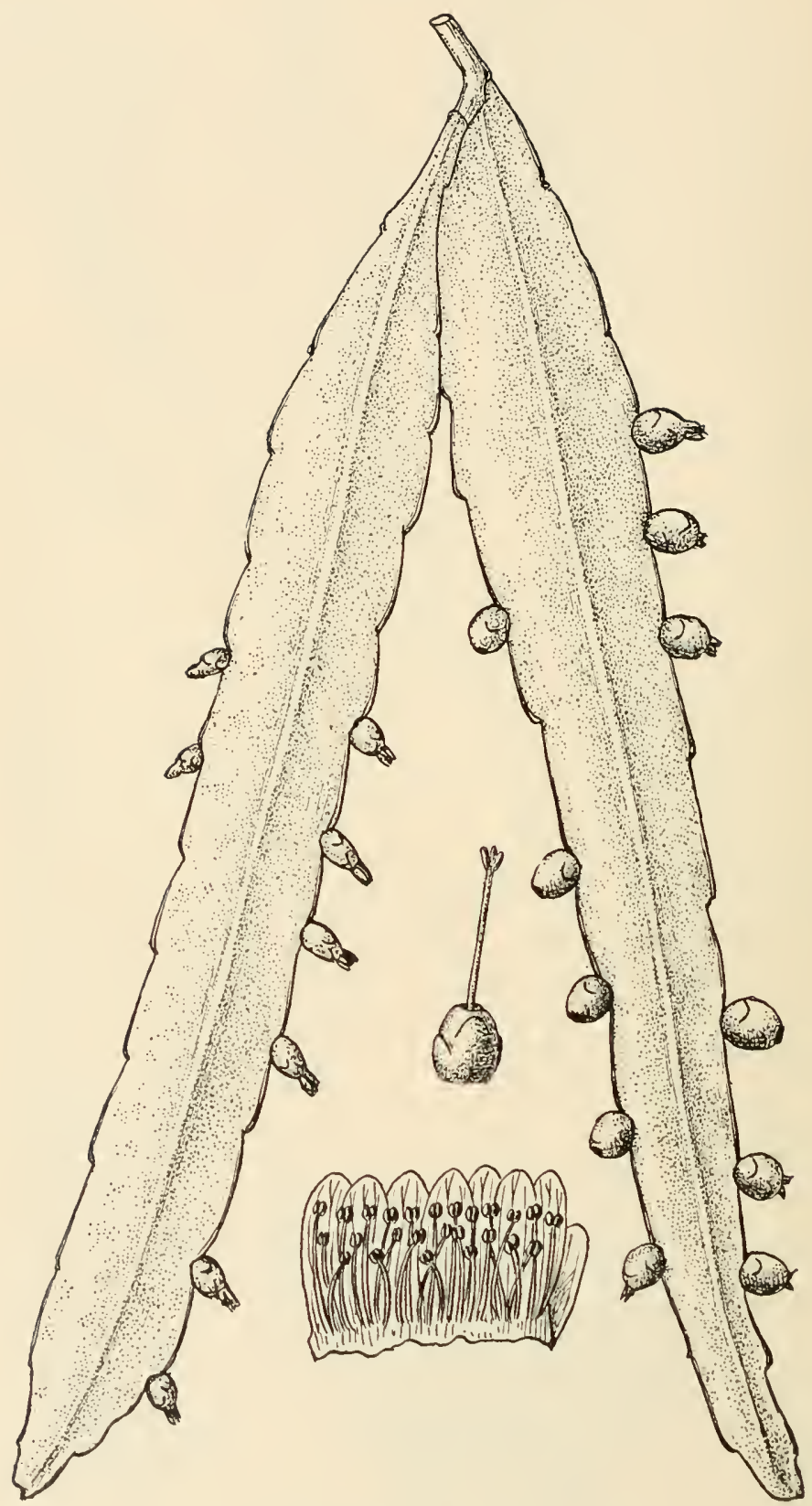

FIG. 3. Rhipsalis jamaicensis Britton \& Harris. 
Jamaica: Woodstock, near Newmarket, Westmoreland (Britton 1583; Harris 9995); Belvidere, Hanover (Harris 7619); Kempshot, Hanover (Britton \& Hollick 2.708); Mandeville, Manchester (Britton 375I). The plant flowers in autumn.

This species has been misinterpreted by authors, commencing with Grisebach (Fl. Br. W. I. 302. I 860) and the name alatus applied to the other somewhat similar plant of Jamaica to be described below. I have satisfactorily identified it from Swartz's description, and by the aid of a tracing of a type specimen preserved in the herbarium of the British Museum of Natural History, kindly sent at my request by Mr. A. B. Rendle, and Professor Urban informs me that the Swartz specimen preserved in the Stockholm Herbarium is also certainly this species.

The name Rliipsalis alata is to be found incidentally mentioned under Cereus alatus in Steudel, Nomencl. ed. 2, I : 333, published in $\mathbf{I} 84 \mathbf{I}$, without any description of the plant referred to, and is therefore a hyponym to be disregarded.

\section{Rhipsalis jamaicensis Britton \& Harris, sp. nov.}

Pendent from trees, the young shoots quite bristly, the older joints smooth; plant $3-10 \mathrm{dm}$. long, the main axis angular; joints $\mathrm{I}-4 \mathrm{dm}$. long, $\mathrm{I}-2.5 \mathrm{~cm}$. wide, dull green, about $2 \mathrm{~mm}$. thick, the apex bluntish, the base narrowed into a stipe $1-6 \mathrm{~cm}$. long, the margins low-crenate; flowers yellowish green, about $6 \mathrm{~mm}$. long, the petals about 7 , oblong to oblanceolate, not very widely expanding, obtusish; ovary oblong, with a few scales; stamens 20-24; style much longer than the three oblong stigmas; berry globose, white, $6-8 \mathrm{~mm}$. in diameter. [Figure 3.]

Jamaica : Troy, Cockpit Country (Britton 5II, type); vicinity of Troy (Maxon 2813); near Montpellier (E. G. Britton 2863); Bath to Cuna Cuna Gap (Britton 3502).

In "Gesamtbeschreibung der Kakteen.," p. 636 , the late Professor Schumann, erroneously describing this plant as Rhipsalis alata, refers the Costa Rican Rhipsalis coriacea Polak. Linnaea $4 \mathbf{I}: 562, \mathbf{I} 877$, to it as a synonym. This species is, perhaps, its closest relative, but after growing the two side by side at the New York Botanical Garden, I am convinced that they are distinct. 
Visitors to the New York Botanical Garden will find the collection of Rhipsalis in Range I, House No. 7, of the public conservatories. 


\section{The New York Botanical Garden}

Sournal of the Now York Botanical Garden, monthly, illustrated, conizining notes, and non-technical articles of general interest. Free to memiers of the Garden. To others, ro cents a copy ; $\$ 1.00$ a year. [Not offered in exchange.] Now in its tenth volume.

Mycologia, bimonthly, illustrated in color and otherwise; devoted to fungi, ncluding lichens; containing technical articles and news and notes of general interest. \$3.00 a year; single copies not for sale. [Not offered in exchange.] Now $\mathrm{n}$ its first volume.

Bulletin of the New York Botanlcal Garden, containing the annual reports of the Director-in-Chief and other official documents, and technical articles embodying results of investigations carried out in the Garden. Free to all members of the Garden; to others, $\$ 3.00$ per volume. Vol. I, Nos. I-5, 449 pp., 3 maps, and 12 plates, I896-1900. Vol. II, Nos. 6-8, 518 pp., 30 plates, I90I-rgo3. Vol. III, Nos. 9-11, 463 pp., 37 plates, I903-Ig05. Vol. IV, Nos. I2-14, 479 pp., I 4 plates, 1905-1907. Vol. V, Nos. I5-18, 463 pp., I7 plates, I906-190; Vol. VI, No. I9, II 4 pp., I go8. Vol. VI, No. 20, II 2 pp., I 909.

North American Flora. Descriptions of the wild plants of North America, including Greenland, the West Indies and Central America. Planned to be completed in thirty volumes. Roy. 8vo. Each volume to consist of four or more parts. Subscription price $\$ 1.50$ per part; a limited number of separate parts will be sold for \$2.00 each. [Not offered in exchange.]

Vol. 22, part I, issued May 22, I905. Rosales: Podostemonaceae, Crassulaceae, Penthoraceae, Parnassiaceae.

Vol. 22, part 2, issued December 18, 1905. Saxifragaceae, Hydrangeaceae, Cunoniaceae, Iteaceae, Hamamelidaceae, Pterostemonaceae, Altingiaceae, Phyllonomaceae.

Vol. 7, part I, issued Oct. 4, I 906 . Ustilaginaceae, Tilletiaceae.

Vol. 7, part 2, issued March 6, I907. Coleosporiaceae, Uredinaceae, Aecidiaceae (pars).

Vol. 25, part 1, issued August 24, 1907. Geraniaceae, Oxalidaceae, Linaceae, Erythroxylaceae.

Vol. 9, parts I and 2, issued December 19, 1907, and March 12, 1908. Polyporaceae.

Vol. 22, part 3, issued June 12, 19o8, contains descriptions of the family Grossulariacere by F. V. Coville and N. L. Britton, the Platanaceae by 11. A. Gleason, the Crossosomataceae by J. K. Small, the Connareceae by N. L. Britton, the Calycanthaceae by C. L. Pollard, and the Rosaceae (pars) by P. A. Rydberg.

Vol. 22, part 4, issued Nov, 20, 1908. Rosaceae (pars) by P. $\Lambda$. Rydberg.

Memolrs of the INew York Botanlcal Garden. Price to members of the Garden, \$1.00 per volume. To others, $\$ 2.00$. [Not offered in exchange.]

Vol. I. An Annotated Catalogue of the Flora of Montana and the Yellowstone Park, by Per Axel Rydberg. is +492 pp., with detailed map. I 1900.

Vol. II. The Influence of Light and Darkness upon Growth and Development, by D. T. MacDougal. xvi $+320 \mathrm{pp}$., with 176 figures. 1903.

Vol. III. Studies of Cretaceous Coniferous Remains from Kreischerville, New York, by Dr. Arthur Hollick and Dr. Edward Charles Jeffrey, viii $+13^{8} \mathrm{pp}$., with 29 plates. 1909

Vol. IV. Effects of the Rays of Radium on Plants, by Charles Stuart Gager. viii +278 pp., with 73 figures and 14 plates. Igo8.

Contalbutious from the New York Botanical Garden. A series of technical papers written by students or members of the staff, and reprinted from journals other than the above. Price, 25 cents each. $\$ 5.00$ per volume. Four volumes.

\section{RECENT NOMBERS 25 CENTS EACH.}

120. Phycological Studies-IV. The Genus Neomeris and Notes on other Siphonales, by Marslaall A Howe.

I2 I. Reproduction by Budding in Drosera, by Winifred J. Robinson.

122. Notes on North American Hypocreales - II. Nectria Peziza, by Fred J. Seaver. 


QL $235 . R 5$ B7 1909
Britton, Nathaniel/Rhipsalis in the West

| I I '

|| || || || |.|.||||||||||||||||||||||||||||||||||||||||||||||||||

35185000883692 


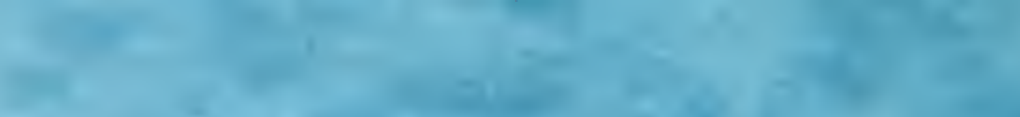

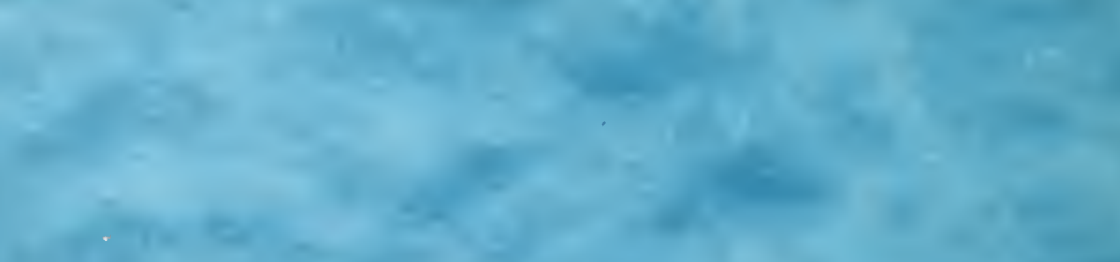

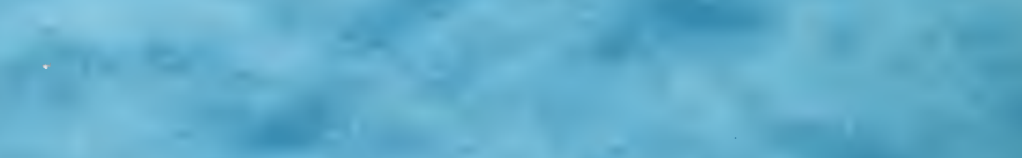

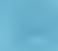

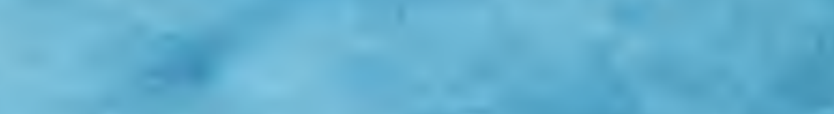

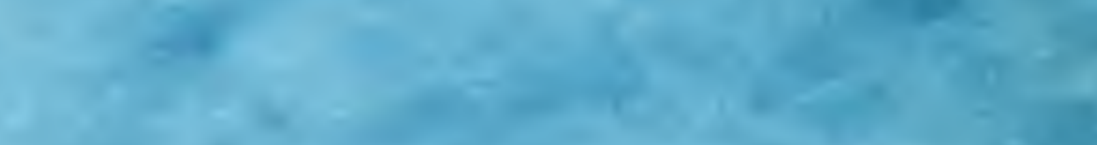

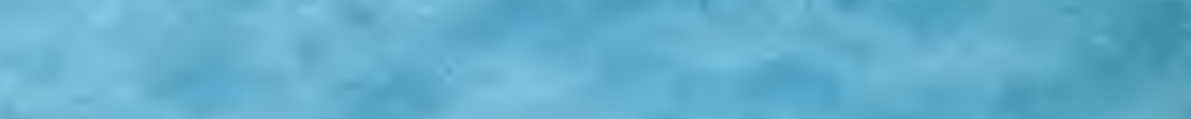
$\sin 20$

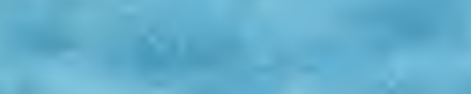
e

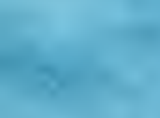
-

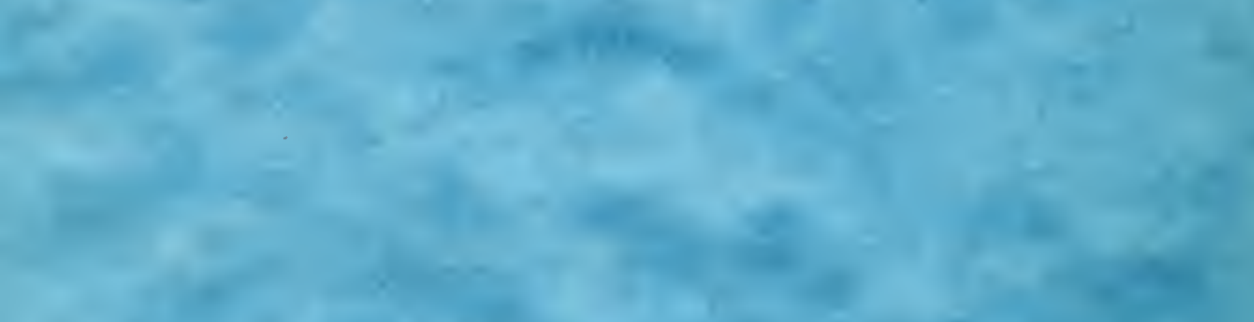

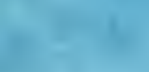

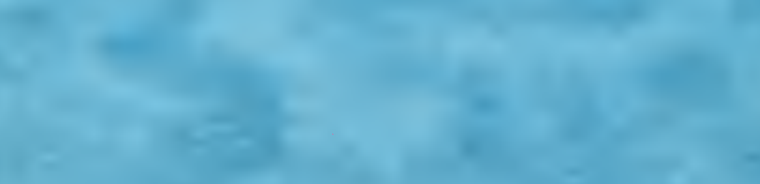

8

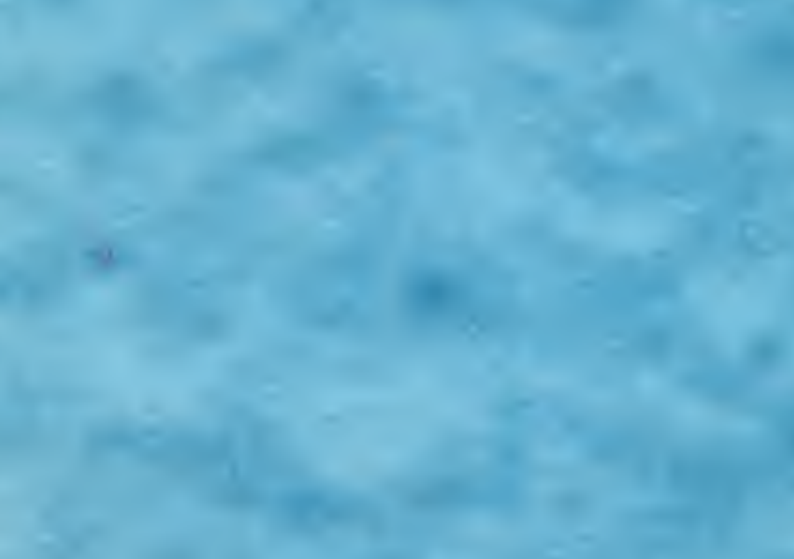

